\title{
AVPR1B wt Allele
}

National Cancer Institute

\section{Source}

National Cancer Institute. AVPR1B wt Allele. NCI Thesaurus. Code C51409.

Human AVPR1B wild-type allele is located within $1 \mathrm{q} 32$ and is approximately $8 \mathrm{~kb}$ in length.

This allele, which encodes vasopressin $\mathrm{V} 1 \mathrm{~b}$ receptor protein, plays a role in adrenocorticotropic hormone regulation. 